\title{
En la voz de un profesor de asignatura de la Facultad de Medicina
}

\author{
Alain Massieu Paulin
}

\begin{abstract}
Resumen
En este video narro un poco sobre mi trabajo como profesor de las asignaturas de Integración Básico Clínica I y II en la Facultad de Medicina de la UNAm y como la pandemia del covid-19 ha cambiado la forma en la que desempeño mi labor docente. También comparto las distintas herramientas, servicios y plataformas que uso para auxiliarme en mi trabajo y procurar realizarlo de la mejor manera. Reflexiono sobre los problemas a los que muchos profesores y alumnos se enfrentan por la brecha digital existente en nuestro país y finalizo haciendo un llamado a replantear y revalorar la labor docente, así como la investigación educativa.
\end{abstract}

Palabras clave: Medicina, TIC, pandemia, UNAM, ABP.

\section{TESTIMONY OF A SUBJECT TEACHER}

\begin{abstract}
In this video I will tell you a little about my work as a teacher at the Basic Clinical Integration I and II firms at the UNAM Faculty of Medicine and how the CovID-19 pandemic has changed the way I do my teaching. I also share the different tools, services and platforms that I use to help me in my work and try to do it in the best way. Reflection on the problems faced by many teachers and students due to the existing digital divide in another country and I conclude by asking for a replanting and revaluation of teaching work, as well as educational research.
\end{abstract}

Keywords: Medicine, ICT, pandemic, UNAM, ABP. 
Alain Massieu Paulin

massieu@gmail.com orcid.org/ 0000-0002-3526-0094

Twitter @alainmassieu

Instagram @alainmassieu

Estudió la carrera de Médico Cirujano en la Facultad de Medicina de la unam y fue durante su servicio social en el Centro de Enseñanza y Certificación de Aptitudes Médicas (CECAM) donde desarrolló un gusto por la educación. Este particular interés lo llevó a realizar una Maestría en Ciencias Sociomédicas, específicamente en Educación en Ciencias de la Salud.

Actualmente labora como profesor de las Asignaturas de Integración Básico Clínica I y II en la Facultad de Medicina de la unAm, su afinidad por la tecnología le ha resultado de utilidad para las clases en esta nueva normalidad. 


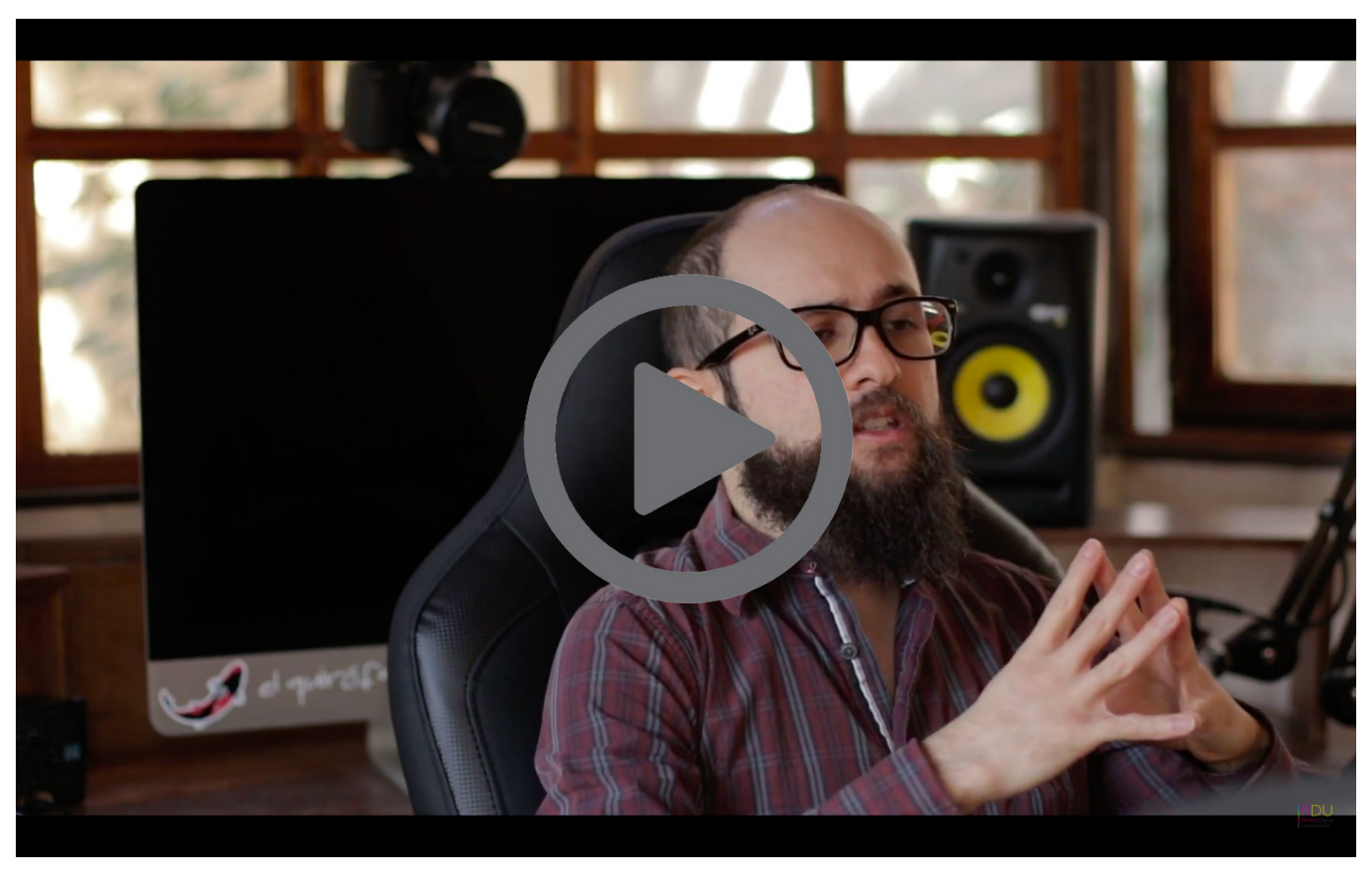

\section{Sitios de interés}

- Massieu Paulin A, Díaz Barriga Arceo F. (2020, 10 junio) Videos educativos en YouTube: una herramienta promotora de habilidades clínicas en estudiantes de medicina. Educación Médica.. https://doi. org/10.1016/j.edumed.2020.03.001

- Massieu Paulin, Alain. (2017, septieembre-octubre). De la experiencia digital a la necesidad formativa. Revista Digital Universitaria (RDU), 18(7). Dol: http://doi.org/10.22201/codeic.16076079e.2017.v18n7.a6.

\section{Cómo CITAR ESTE ARTículo}

* Massieu Paulin, Alain. (2021, enero-febrero). En la voz de un profesor de asignatura de la Facultad de Medicina. Revista Digital Universitaria (RDU), 22(1). Dol: http://doi. org/10.22201/cuaieed.16076079e.2021.22.1.22 